\title{
MAKING Homes IN LimbO: Embodied Virtual “Homes" in Prolonged Conditions of Displacement
}

\author{
Giorgia Doná
}

\begin{abstract}
This special issue makes an original contribution to our understanding of the meaning of home by introducing the idea of the constellation of HOME-Home-home and homemaking practices where these are not necessarily foreseen, in contexts of displacement. In this article, I argue that we need to distinguish between humanitarian-driven understandings of "protracted refugee situations" and peoplecentred experiences of "prolonged conditions of displacement." I show how the papers in the special issue bring to the fore inconsistencies between state-centred perspectives and people-centred meanings of the "constellation of homes." Lastly, I examine the significance of other spaces where home may be made during prolonged displacements: the virtual space. I conclude by suggesting that we need to examine in greater depth the complex relationship between the dwelling, home, and homemaking practices when these occur in material and de-territorialized virtual spaces.
\end{abstract}

\section{Résumé}

Ce numéro spécial de Refuge apporte une contribution originale à la façon dont nous concevons l'idée de "domicile» en postulant la constellation triadique de DOMICILEDomicile-domicile ainsi que les pratiques reliées à l'établissement d'un domicile dans des contextes parfois inattendus, en ce qui concerne les situations de déplacement.

Dans cet article, j'avance qu'il faut distinguer entre les conceptions humanitaires reliées aux "situations de réfugiés prolongés» et les expériences en "conditions prolongées de déplacement» axées sur les individus. Je montre comment les articles dont le numéro spécial est composé font ressortir les désaccords inhérents entre les perspectives étatiques et les conceptions expérientielles des individus autour de cette "constellation" triadique de "domicile». En dernier lieu, je me penche sur l'importance d'autres espaces qui pourraient servir de contexte à l'établissement d'un domicile en situation de déplacement prolongé, notamment l'espace virtuel. Pour conclure, je propose qu'on réexamine en profondeur la relation complexe entre les pratiques de logement, de domicile, et d'établissement de domicile dans leur actualisation matérielle ainsi que dans le contexte d'espaces virtuels déterritorialisés.

\section{Introduction}

My contribution to this special issue is an examination of three issues that arise in response to the innovative material presented in the volume: (1) the distinction between "protracted refugee situations" and "prolonged conditions of displacement," (2) the tension between state-centred and people-centred perspectives of home in the "constellation of homes," and (3) changes in the meaning of home and homemaking practices when these occur in de-territorialised virtual spaces.

\section{From Protracted Refugee Situations to Global Conditions of Prolonged Displacement}

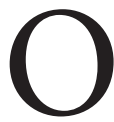
ver the last few decades, migration patterns have increased in frequency, speed, and categories. More migrants, including forced migrants, women, and 
minors move from and to more countries and use diversified routes. ${ }^{1}$ The consolidation of a dominant Western political strategy referred to as securitization of migration ${ }^{2}$ has further altered these conditions. One main effect of these changed environments and patterns has been the increased number of individuals caught in territorial, spatial, and bureaucratic limbo. The State of the World's Refugees: In Search for Solidarity ${ }^{3}$ reports that 7.2 million people now live in "protracted refugee situations" out of the thirty million people under the protection of the United Nations High Commissioner for Refugee (UNHCR) mandate, which include ten million refugees.

The term protracted refugee situations is now commonly used by UNHCR, even though it has not been formally defined or elaborated by the organization, ${ }^{4}$ and forced migration scholars too have used it. 5 Its use gives visibility to the circumstances of those millions of individuals across the world who have been granted refugee status and for whom a permanent solution-settlement, resettlement, or repatriation-cannot be reached within five years. The concept of protracted refugee situations defines a distinct legal status (refugee) and temporal framework (five-year period).

Individuals make homes or engage in homemaking practices while living in conditions of uncertainty that are outside the UNHCR definition of "protracted refugee situations": asylum-seekers waiting to be granted protection; undocumented migrants living in "hiding" in urban areas; asylum-seekers in detention centres; individuals caught in "temporary" administrative vacuums such as unresolved residency permission; others waiting to be repatriated, and those who are "in transit" from one place, one state, to the next.

New patterns of migration and increased securitization of migration have led to the emergence of a new globalized phenomenon: prolonged conditions of displacement. In the global South and North contexts that are different, at first sight, such as refugee camps, urban areas, or detention centres, are brought together through their becoming sites where forced migrants experience forced immobility and where humanitarian agencies implement policy-driven temporary solutions. In these globalized contexts ${ }^{6}$ of dis placements, forced migrants turn shelters into homes and engage in homemaking practices.

The legal/policy-driven term protracted refugee situations does not cover these new transnational contexts of prolonged transit that forced migrants experience in the age of securitization of migration. Broader concepts like "prolonged conditions of displacement" or "prolonged displacements" are better suited to describe the ongoing disruptions that different groups of forced migrants experience across multiple environments of long, drawn-out uncertainty.
The use of the term prolonged displacements is useful when considering the experiences of forced migrants themselves. Protracted refugee conditions and prolonged displacements are distinct concepts. The first emerged in response to policy and humanitarian concerns. It is policy- or agency-driven. The concept of prolonged displacements is people-centred. It considers sociological and experiential elements of forced migrants' experiences. For forced migrants, prolonged conditions of displacement are about spatial, temporal, or bureaucratic states, and they also encompass emotional and relational qualities. United Nations and humanitarian assistance agencies consider "contexts," "conditions," and "solutions." Forced migrants speak of homes, homemaking, and belonging.

Contributors to this special issue examine different contexts of prolonged displacement. Their articles bring to the fore inconsistencies between state-centred perspectives and people-centred experiences. Čapo compares the lives of former refugees from Bosnia and Herzegovina and Croatia, and argues that, unlike the language of durable solutions proposed by states and international agencies, neither "repatriation" nor settlement (local integration) brought "durable solutions" to refugee predicaments but resulted in a period of prolonged displacement and liminality.

Trapp's article reveals the incongruity between statecentred and individual-centred perspectives in the context of homemaking practices in refugee camps. Trapp argues that Liberian refugees in the Buduburam camp live in a paradox of settled life-visible in their homemaking practiceswithin the broader context of the refugee camp, a temporary space that becomes a space of long-term residence as a result of political constraints.

Fábos and Brun highlight the inconsistencies between state- and people-centred perspectives on prolonged displacement for less visible groups, namely urban refugees and internally displaced. Long-staying urban refugees are not typically included in state-centred understanding of "protracted refugee situations," and yet many across the world live clandestinely in urban areas, avoiding contact with the authorities and bereft of legal status for years. Excluded from both domestic citizenship and international recognition as refugees, Fábos's Sudanese participants were obliged to navigate an ambiguous and uncertain policy environment. Their prolonged uncertainty shaped their ability to feel "at home" and to be able to "make home" in Egypt in specific ways. Brun examines long-term displacements of Abkhazians who fled to Georgia in the early 1990 s following claims of independence from Georgia. As internally displaced, they are less visible in international discourses on durable solutions. Brun assesses how the construction of "block houses" that promote "durable housing solutions" 
changed their perceptions of home, and she explores how shelter, housing, home, and homemaking can be conceptualized in the context of prolonged displacement.

This special issue addresses an important dimension of forced immobility - the meaning of home and the practice of homemaking - in conditions of prolonged displacements from a people-centred perspective. It conceptually distinguishes between the state policy-oriented focus of "protracted refugee conditions" with its "distinct legal status (refugee) and temporal framework (five-year period)," and the people-centred focus of "global situations of prolonged displacement." The use of the term protracted (lasting for a long time or longer than expected or usual) has now become thoroughly associated with UNHCR, U.S. State Department, etc., and this is why the term prolonged is being introduced: to highlight the people-centred language that describes these global situations.

\section{Tensions in the Constellation of home, Home and HOME}

In the editorial introduction to the special issue, Brun and Fábos describe a new conceptual framework to explain how and why people who live in ongoing displacement engage in the process of making homes. The framework distinguishes among three kinds of homes-HOME, Home, and homeand it suggests that we examine their relationship through the concept of "constellation of homes." HOME refers to the broader political and historical context in which home is understood and experienced, and to the homeland as defined by the national borders of nation-states; Home describes forced migrants' memories of, longing for, and imaginations of homes that are idealized; and home describes day-to-day practices and meanings individuals give to the places they inhabit. The constellation of homes is a welcome conceptual contribution to the literature on home in general 7 and in contexts of displacement and forced migration. ${ }^{8}$ It enables us to consider each component of the triad independently and to assess their relationship within the "constellation of homes." Therefore, in addition to decoupling "home" and "homeland"9 and deconstructing refugees as people out of place, there is a need to disentangle the home triad, and the editors beautifully accomplish this task in presenting the elements that form the constellation of homes.

In this section, I shall examine in greater depth the relationships among the components of the home triad, and I shall do so in three ways: territorially, temporally, and socio-legally/administratively. In doing so, I shall highlight the complex relationships and sometimes tensions that exist between state-centred and people-centred perspectives of home, Home, and HOME in prolonged displacement: forced migrants' meaning of home may challenge or exceed nation-states' constructions of HOME, while the concept of Home may fulfil a mediating role by bringing together the perspectives of nation-states and those of forced migrants, and integrating elements relevant to both categories of social actors.

Nation-states and international refugee organisations, most notably UNHCR, continue to view HOME primarily in territorial terms and to be synonymous with homeland. Refugees and returnees are said to be at HOME when they are (re)-settled across regional borders, have moved to resettlement societies, or are back in their countries of origin, independently of where they end up making their homes. Eastmond and Öjendal, ${ }^{10}$ among others, show that while from the state-centred perspective, Cambodians' return HOME is understood as their crossing of national boundaries, individuals' return to familiar and unfamiliar areas has a significant impact on the ways in which returnees perceive "returning home" and make their "new" homes. Muggeridge and Doná ${ }^{11}$ show the profound impact that the first visit home, which sometimes but not always coincides with their imagined "Home" and the borders of the national HOME, has on refugees' re-assessing the meaning of "home" and re-connecting with HOME-Home-home.

The state-centred understanding of HOME constructed through nation-states boundaries and citizenship rights is in tension with the UN-HOME that stateless people, for instance, are confronted with. Like other forced migrants and displaced populations, they inhabit "spaces of exception," spatially confined areas that are situated inside the HOME defined by nation-state borders but where refugees and forced migrants are not citizens and do not belong to the nation-state's view of being at 'HOME'. Bauman, ${ }^{12}$ for instance, describes refugees camps, an example of UN-HOME, as being "in" but not being "of" the countries in which they are located. He goes on to show how refugees from different parts of Africa who live together in refugee camps in Kenya transform standardized spaces into homes by delineating boundaries, giving them familiar names and embellishing them with symbolic pictures.

States and agencies' HOMEMAKING (in capital letters to distinguish this practice from people-centred homemaking) endeavours consist in supporting refugees and returnees to (re)settle in their territorially defined HOMES. These efforts are different from those provided through humanitarian assistance, which supports the constructions of shelters (not homes) as part of their efforts to ensure individual and collective survival. HOMEMAKING appears not to be vital in situations of temporary displacements. As we have seen, the increase in frequency and duration of protracted refugee conditions, and protracted displacement more generally, challenges current state-centred practices 
of HOMEMAKING, and prompts the analysis of how states and agencies can promote HOMEMAKING during prolonged displacements.

In addition to the spatial dimension discussed above, there is a temporal element to the understanding of the constellation of homes, and the tension between HOME, Home, and home. From a state-centred perspective, refugees and forced migrants are at HOME when they have successfully met the requirements of long-term residence as they settle, resettle, or repatriate. Thus, forced migrants and refugees are at HOME if a permanent solution to their "refugee condition" is found within a short period of time, recently codified by five years. This period signals the temporal boundary between temporary and protracted refugee situations, and it indicates the transition from one to the other. As we have seen, people living in prolonged displacement are caught in the paradoxical situation whereby the permanency of temporary solution has become recognized and it has even been codified. Life in UN-HOME contexts (protracted refugee situations) has become normalized.

From a people-centred perspective, the temporal analysis of HOME, Home, and home exposes a more complex relationship, and longer time frame. It is in the transformation of one or more elements of the home triad, and their combination, that we can better understand how forced migrants make their homes in prolonged displacement. This ranges from loss of past home, Home, and HOME, to aspirations to make a new home, Home, and HOME in the future, and engagement with HOME, Home, and homemaking practices in the present. Changes in the relationship among the home triad are visible the emergence of new forms of embodied practices, transformations of dynamic relations, and evolving emotional attachments.

The homemaking practices of Somali refugee women living in Australia offers a poignant example of these transformations. It is through Islamic rituals such as daily prayers that these women are able to feel at home in unfamiliar environments because, as they say, "Everywhere is Allah's place."13 Through dynamic homemaking practices, the Home for the past and that of the future is actualized in the present. The distinction of the three components of the triad helps us to grasp the tensions between territorial and temporal dimensions that have different and divergent meanings for different social actors.

The third and final way to examine the tensions between HOME, Home, and home in protracted situations of displacement is through the socio-legal-administrative lens. From a state-centred perspective, forced migrants are at HOME when they have gained some sort of permanent status like refugee or citizenship status in receiving societies or have regained citizenship status upon return to their countries of origin. To obtain permanent status means to be entitled to the same rights granted to HOME citizens (such as employment, education, identity, vote, etc.). Nonpermanent socio-legal status, such as being an asylumseeker or having being granted humanitarian protection or temporary protection has become widespread, and for some groups or countries it has completely replaced permanent status.

As the securitization of migration gains prominence and restrictive migration management practices intensify, non-permanent status is becoming the "majority status," as shown, for instance, in the 2012 State of the World's Refugees report, which indicates that two-thirds of the thirty million people under UNHCR's mandate have not been bestowed refugees status. The end of permanency is in sight: recent changes in UK legislation, for instance, have led to the revocation of permanent protection status, even to Convention refugees, whose refugee status is now going to be reviewed after five years. ${ }^{14}$ Temporary and protracted solutions have become the "permanent norm." The five-year period sanctions a new way of thinking about the relationship between temporary and permanent conditions. It also marks the creation of a new phase in the experience of forced migration: prolonged displacements.

Forced migrants fleeing persecution, human rights abuses, and generalized violence increasingly experience a new type of temporariness, one of administrative limbo (and for undocumented forced migrants this condition may be for the duration of their forced migration). This condition subjects forced migrants to ongoing relationships with the HOME Office (the UK department responsible, amongst others, for immigration), and restrictions in official opportunities for homemaking. This results in forced migrants having to find innovative homemaking ways to feel that they belong, at least partially. The last section will describe one such type of new homemaking practice in virtual spaces.

From a people-centred perspective, it is important to keep the three components of the home triad distinct, and to examine their complex relationship. Forced migrants' meaning of home is expressed through their engagement with one component of the triad, or a combination of them. The process is more complex than the state-centred one reliant on the conflation of the three components to only one. In the past, the hegemony of state-centred perspectives meant that the achievement of permanent territorial, temporal, and administrative status was identified with being at home, and this was on the basis of the conflation of the concepts of homeHome under that of HOME. The examination of the meanings of home in protracted conditions of displacement allows us to disentangle the conflation of the home triad in response to the changes that are taking place globally. In addition to 
separating the three elements of the home constellation, we must also be aware that the three components themselves are shifting in meaning from solid and durable states to transient and fluid conditions, and that the tension expresses these discrete and relational transformations.

The significance of this special issue rests in its timely and innovative contribution to ongoing discussions on the meaning of home in a changing world. In the past, only a minority of forced migrants found themselves stuck in conditions of prolonged displacements. The increase in frequency, diversification, and creation of new conditions of prolonged displacements means that they have become the "permanent norm" for those fleeing persecution and generalized violence, and they have become the "majority status" for those in need of protection. Hence, the value of understanding how forced migrants make homes in these new contexts.

This special issue makes an original contribution to our understanding of the constellation of HOME-Home-home and homemaking practices by examining them in contexts that are conventionally associated with homelessness, transit, and un-homey conditions. The edited volume challenges the assumption that HOME-home = rootedness and that forced migration $=$ HOME-homelessness in a novel way that goes to the core of the problematic equations outlined above. It examines the meaning of HOME-home and homemaking precisely where these are not necessarily foreseen, in UN-HOME-Homely contexts.

Contributors challenge conventional scholarly and policymakers' assumptions that those forced to leave their homes feel homeless (Brun, Fábos, Trapp), that return equals HOME-home-coming (Čapo), and that those living in temporary shelters do not feel at home (Brun, Trapp). They all show that homemaking practices are ongoing, even when people live unsteady lives as they try to improve their material conditions (Brun, Trapp) and recreate familiarity and belonging in their new environments (Brun, Čapo, Fábos, Trapp). Overall, contributors to the special issue give examples of where and how forced migrants make homes and engage in homemaking practices in protracted conditions of displacement without romanticizing the experience of home and homemaking that takes place during displacement. Their aim is to enable a more complex understanding of the relationship between home and forced migration, between home and homelessness. They examine the ways in which settling and unsettling take place simultaneously for many forced migrants.

In a changed global landscape, forced migrants living in prolonged conditions of displacement have found new ways of making homes that challenge conventional meanings, as shown by the contributors of the edited volume. Brun identifies how decorating, expanding, and renovating shelters are homemaking strategies through which internally displaced Abkhazians transformed shelters into homes in Georgia. Fábos examines mobile homemaking strategies such as visiting by which Sudanese made and remade home in Cairo. Čapo adds complexity to the understanding of homemaking by showing that for former refugees from Bosnia and Herzegovina and Croatia homemaking needs to be considered at different scales-the dwelling; the locality, the latter (locality) embracing a natural (landscape), cultural (built environment, symbolic meanings, gestures) and social (networks) aspect/component of belonging; and the wider social and (ethno) political context. Additionally, intra- and interstate trans-locality is a strategy to ensure sustainable livelihoods and promote new ways to belong. Trapp too shows the relevance of transnational homemaking practices for Liberian refugees in Ghana, for whom homemaking was rooted in a preference for resettlement to the United States, such that travel to America provided refugees with the necessary status to belong and survive at "home" in Liberia.

In the next section I shall examine an additional innovative way of making homes in virtual space. Forced migrants' increased access and use of information and communication technologies inspires them to create de-territorialized homes and virtual homemaking practices.

\section{De-Territorialized Homes and Virtual Homemaking Practices}

Living in prolonged displacements, forced migrants find new ways to create homes away from the dwelling and towards non-territorialized settings such as online communities. Forced territorial and bureaucratic immobility is reversed in virtual spaces, where forced migrants are free to navigate, to enter in dialogue with co-ethnic, co-national, and also transnational and trans-generational others, and to feel "at home" among online communities. "Home" is a highly fluid and contested site of human existence that reflects and reifies identities and values. For many individuals in prolonged displacement, the material conditions of encampment, detentions, surveillance, etc., are one of the reasons why "home" would be found elsewhere, for instance through home-making in de-territorialized spaces.

Virtual homemaking can be seen in the ways in which refugees use Internet cafés in refugee camps to keep in touch with those who have left the camps and are in the diaspora. ${ }^{15}$ Through Skype calls and email exchanges, Somali refugees confined in protracted situations of displacement transcend their immobility by interacting with family members and friends in transnational spaces. ${ }^{16}$ These online and web interactions contribute to maintain the Home in the past and to 
foster aspiration to reach new Homes in the future. Meanwhile, remittances sent back to those in need through "online" banking transactions and mobile phones help with the improvement of physical dwellings in camps and their becoming homes.

Asylum-seekers confined in detention centres rely on mobile phones to keep in touch with the "outside world" in receiving societies. ${ }^{17}$ Mobile phones become functional tools for overcoming isolation and the main channel of communication with outsiders, and connecting with the world. Like computers, mobile phones come to symbolize home. They make it possible to connect with family and friends, and to experience intimacy at a distance. Thanks to mobile phones, detained asylum-seekers manage to hold onto the family and the familiar. These examples show the relationship between the material and the virtual, and the significance of the location/dwelling relative to other spaces where home may be made, namely the virtual space. Materiality plays a role in the location of the Internet café and in the technology being used. There is a need to examine in greater depth the complex relationships between the dwelling, home, and the domestic in material and virtual spaces.

In virtual space, forced migrants and e-diasporas can feel virtually part of their HOME country, which they cannot physically visit, by accessing news and sharing information with other members of their ethnic and national group when they are not able to meet in person. ${ }^{18}$ Similarly to Anderson's imagined community, ${ }^{19}$ ethnic and national groups create imagined virtual communities that, similarly to the one proposed by Anderson, are very powerful. In virtual space lost homes are located, imaginations of idealized Homes are strengthened, memories of the Home of the past are relived, and future homes are visualized. Bernal, ${ }^{20}$ for instance, shows how the Eritrean diaspora online strengthens their political imagination of the home triad through the web, while Anat ${ }^{21}$ describes how the Palestinian diaspora moves between de-territorialization and re-territorialization homemaking practices, and Doná ${ }^{22}$ outlines the role of cyber-memorialization in creating new spaces for spoken, unspoken, and unspeakable stories of the past, and in doing so, HOME was reinvented.

Forced migrants' homemaking practices accompany them in their everyday movements/mobilities as well as in new/non-territorial locations where they develop new homes and forms of belonging. ${ }^{23}$ This new practice challenges the notion of "home" as domesticity and shows that displacement may lead to a shift in homemaking practices and in new/non-territorial locations for the production of home.

\section{Conclusion}

This special issue addresses an important dimension of contemporary experience of forced migrants-the meaning of home and the practice of home-making-in conditions of prolonged displacements. The people-centred approach of the special issue offers an innovative understanding of the complex relationship between home and displacement. Contributors offer detailed examples of where and how forced migrants make homes and engage in homemaking practices in protracted displacement, showing the complexity of home and homemaking rather than romanticizing them. The special issue makes an original contribution to our understanding of the constellation of HOME-Homehome and homemaking practices by examining them where these are not necessarily foreseen.

The contributors challenge conventional scholarly and policymakers' assumptions that those forced to leave their homes feel homeless, that return equals HOME-homecoming, and that those living in temporary shelters do not feel at home. They all show that homemaking practices are ongoing, even when people live unsteady lives as they try to improve their material conditions and recreate familiarity and belonging in territorialized and de-territorialized environments.

The special issue as a whole offers an interesting approach for future research on the meaning of home. Future studies will need to focus on the examination of complex and related meanings of HOME-Home-home, and in underresearched contexts where homemaking takes place, including unexpected, invisible, and de-territorialized spaces.

Giorgia Doná is professor of forced migration and refugee studies at the University of East London and fellow of the Higher Education Academy. She has been researching and writing in the area of forced migration for almost thirty years. Her research focuses on forced migration and refugee movements, child protection, psycho-social interventions, and participatory research methodologies. Her recent publications include Child and Youth Migration: Mobilityin-Migration in an Era of Globalisation (2014, Palgrave, with Angela Veale), "Research Methodologies in Forced Migration," special issue, Journal of Refugee Studies (2007, with Eftihia Voutira); "Child and Youth Migration," special issue, International Journal of Migration. The author may be contacted atG.Dona@uel.ac.uk.

\section{Notes}

1 Stephen Castles and Sean Loughna, "Trends in Asylum Migration to Industrialized Countries, 1990-2001," in Poverty, International Migration and Asylum, ed. G.J. Borjas and J.Crisp, 39-69 (London: Palgrave, in association with the UN University, 2005); Giorgia Doná, "Changing 
Migration Patterns and Responses in the Context of Child and Youth Forced Migration," International Journal of Migration, Health and Social Care 2, no. 2 (2006): 2-6.

2 Jef Huysmans, "The European Union and the Securitization of Migration," Journal of Common Market Studies 38, no. 5 (2000): 751-77.

3 United Nations High Commissioner for Refugees, The State of the World's Refugees: In Search for Solidarity (Oxford: Oxford University Press, 2012).

4 Jeff Crisp, "No Solutions in Sight: The Problem of Protracted Refugee Situations in Africa," Working Paper no. 75 (Geneva: United Nations High Commissioner for Refugees, 2003).

5 James Milner and Gil Loescher Responding to Protracted Refugee Situations: Lessons from a Decade of Discussion, Forced Migration Policy Briefing 6 (Oxford: Refugee Studies Centre 2011).

6 Giorgia Doná and Angela Veale, "Divergent Discourses, Children and Forced Migration," Journal of Ethnic and Migration Studies 37, no. 8 (2011): 1273-89.

7 Shelley Mallett, "Understanding Home: A Critical Review of the Literature," Sociological Review 52, no. 1 (2004): 62-89.

8 Giorgia Doná and John Berry, "Refugee Acculturation and Re-acculturation," in Refugees: Perspectives on the Experience of Forced Migration, ed. A. Ager, 169-95 (London: Continuum, 1999); Laura Hammond, This Place Will Become Home: Refugee Repatriation to Ethiopia (Ithaca, NY: Cornell University Press, 2004); Maja Korac, Remaking Home: Reconstructing Life, Place and Identity in Rome and Amsterdam (New York: Berghahn Books, 2009); Helen Taylor, "Refugees, the State and the Concept of Home," Refugee Survey Quarterly 32 (2013): 130-52.

9 Korac, Remaking Home, 25.

10 Marita Eastmond and Joakim Öjendal, "Revisiting a 'Repatriation Success': The Case of Cambodia," in The End of the Refugee Cycle? Refugee Repatriation and Reconstruction, ed. R. Black and K. Koser, 38-55 (Oxford: Oxford University Press, 1999).

11 Helen Muggeridge and Giorgia Doná, "Back Home? Refugees' Experiences of the First Visit Back to Their Country of Origin,” Journal of Refugee Studies 19, no. 4 (2006): 415-32.

12 Zygmunt Bauman, "Up the Lowly Nowherevilles of Liquid Modernity: Comments on and around Agier," Ethnography 3 , no. 3 (2002): 343-49.

13 Celia McMichel, “'Everywhere is Allah's place': Islam and the Everyday Life of Somali Women in Melbourne, Australia," Journal of Refugee Studies 15, no. 2 (2002): 171-88.

14 Home Office website, 2013, http://www.ukba.homeoffice. gov.uk/asylum/outcomes/.

15 Tiziano Bonini, “The Media as 'Home-making' Tools: Life Story of a Filipino Migrant in Milan," Media, Culture and Society 33, no. 6 (2011): 869-83.

16 Cindy Horst, "Virtual Dialogues? The Value of Electronic Media for Research among Refugee Diasporas," Refuge 23, no. 1 (2006): 51-7.

17 Linda Leung, “Taking Refuge in Technology: Communications Practices in Refugee Camps and Immigration Detention," New Issues in Refugee Research, research paper 202 (Geneva: United Nations High Commissioner for Refugees, 2011).

18 Giorgia Doná, "Forced Migration, and Material and Virtual Mobility among Rwandan Children and Young People," in Child and Youth Migration: Mobility-in-Migration in an Era of Globalisation, ed. A. Veale and G. Doná, 113-39 (Basingstoke, UK: Palgrave, 2014).

19 Benedict Anderson, Imagined Communities: Reflections on the Origin and Spread of Nationalism (London: Verso, 1982).

20 Victoria Bernal, "Diaspora, Cyberspace and Political Imagination: The Eritrean Diaspora Online," Global Networks 6, no. 2 (2006): 161-79.

21 Ben-David Anat, "The Palestinian Diaspora on the Web: Between De territorialisation and Re-territorialisation," Social Science Information 51, no. 4 (2012): 459-74.

22 Doná, "Forced Migration."

23 Sandra M. Gifford and Raelene Wilding, "Digital Escapes? ICTs, Settlement and Belonging among Karen Youth in Melbourne, Australia," Journal of Refugee Studies 26, no. 4 (2013): 558-75. 
(C) Giorgia Doná, 2015. This open-access work is licensed under a Creative Commons Attribution-NonCommercial 4.0 International License, which permits use, reproduction and distribution in any medium for non-commercial purposes, provided the original author(s) are credited and the original publication in Refuge: Canada's Journal on Refugees is cited. 